\title{
Wriezener Park, Berlin From a old train lot to a Green Biotope ${ }^{1}$
}

\author{
Bruno Marques, Technische Universität Berlin \\ Project coordinated by Mrs. Cordula Loidl-Reisch and Mr. Simon Colwill
}

\begin{abstract}
A brief introduction
All of us know the Berlin's recent history: a city swallowed by the Second World War's voracity, only recently regaining its previous dimension, still in reconstruction process and searching for its lost identity. A multicultural city, polycentric, united and divided by the magic from the past, with all its greatness and shame. Here the future is built burying the ghosts from the past - some of them distant but others still present in the memory that pursues us.
\end{abstract}

Though still in the process of reconstruction, the past is a tangible reality throughout Berlin. By walking the city we realize that the magic component is present in its magnificent buildings and extensive green spaces. For all this, the past reflects itself in the actions and perceptions that take place in this city.

It was in this context that the project appeared: located in the east part of the city, in "the other one" Berlin: a residential area today filled with young people that cohabite with the older generation whose difficult past is still alive and active. This older generation is greatly responsible for the decisions that shape the future of Friedrichshain's district and they remember the past and hesitatingly move forward, overcoming their own fears.

\section{Historical context}

Let's go back to the past so that we can understand the context and motives behind the changes that took place. Berlin grew rapidly from the late 1800s to the Second World War era, and in 1920, it swallowed up surrounding suburbs to become Gross-Berlin (Greater Berlin). Like many expanding cities during this time, Berlin employed a combination of rail options to reduce traffic congestion.

In the midst of S-Bahn Warschauer Straße and S-Bahn Ostbahnhof train stations, main poles for the circulation of the eastern Berlin population, once full of life but nowadays dissolved in the wild vegetation that seems to be trying to hide mistakes made by men in the past 150 years.

In 1898 construction began on the urban lines, east to west, from Lichtenberg until Wriezen. The town's growth and the rising passenger numbers induced, in 1903, the redesign of these rail tracks lines and their expansion towards Schlesischen Bahn (now Ostbahn), near to Wriezen bahn, heading west.

\footnotetext{
${ }^{1}$ Biotope is an area of uniform environmental conditions providing a living place for a specific assemblage of plants and animals. Biotope is almost synonymous with the term habitat, but while the subject of a habitat is a species or a population, the subject of a biotope is a biological community. (Connor 1995, Hiscock 1995)
} 
In 1950 the decision is made to alter the names, Schelesischen Bahn permanently becomes Ostbahn due to its evolution and also due to its rail connections with Wriezer bahn, only functioning as a railroad hub.

The definitive closure of Wriezer Bahn to its passenger's dates to 1949, with Ostbahn assuming its functions. The Wriezer Bahn lines are reserved for post office services. This alteration drove to the isolation and degradation of the site. (BF-K, 1997) Then, in 2005, most of the railroad lines are removed; amongst them the ones that_were used to built the train wagon, isolating the huge iron architectural building, like a heart without its arteries. Some of these 'internal organs' are still present in our project's site, others are forever gone.

In 2006 begins this site's expansion with the construction of two big commercial surfaces (Metro and Obi), based on sealing construction materials, isolating all the area previously belonging to the Wriezer Bahn station that still names the site. (BBR, 2007)

\section{Area Description}

All the future park area, almost 5ha, was integrated in 2007 on the city, by the green department, as a potential plants and animal biotope.

Also happens in 2007 that Wriezener Park process was inserted on the city public project platform of restoration of old railway train lots (like Gleisdreieck project ${ }^{2}$ ). These projects are supported by the local community ideas.

Although the 'Freifunk-Hain' idea happened before in 2003. A free WLAN platform was developed by the local community for all the residents - Freifunk 'Communitree'. WLAN platform is a Wireless Local Area Network, based on radio waves which permits the users by connected to the network, using internet system, without wires. For along 4 years, the free WLAN connection generates on the community, the idea of expansion of this free service for a public space when all can use it.

Being an area in development, the Freidrichshain's district presents a majority young population living there, but wrapped up for a very active community in the public decisions who makes all the future project decisions extremely connected with these community ideas.

The Project area is limited in northeast side by habitation buildings and in southwest by the Spree River. In the exposed areas to northwest grew in the last years big commercial surfaces that blocked the connection with Ostbahn station, and on southeast the area continues besides Warschauer Straße Station.

In the connections way, the whole space is in a privileged geographical position, since all the main transports are next and several cycle roads cross the principal communication points. An internal problem of circulation is connected with the southwest limit where some railway tracks still remain, making a physical barrier as an obstacle in the connection with both sides of the park.

Besides that, inside the park is a historical building connected with past of maintenance and repair of old rail machinery, but under historical preservation - Lokschuppen since the times when Wriezener Bahn was shut downed. This building from iron architecture period will have a special position on the structural concept of the park.

\footnotetext{
${ }^{2}$ Gleisdreieck area is composed by 35 ha from an abandoned railway "triangle" hub intersection. Nowadays is a big biotope connecting Potsdamer Platz to Tiergarten, keeping all the wild vegetation which grew along the years and also an open air art exhibition. For further information check www.berlin-gleisdreieck.de
} 


\section{"Freifunk-Hain" concept}

The project consists of rebuilding a semi-abandoned area and giving it to Wriezenern Park residents. It will be a biotope in the city's heart, near the Ostbahnhof train station. The concept held two main ideas: an outdoor WLAN space connected through the Freifunk 'Communitree' network and a self-sustainable energy space.

These two elements hold the conceptual idea for a 'Freifunk-Hain' as a public platform for a communicative and social network of different groups and with the local population. Using the open WLAN source since 2003, this 'Hain' resembles a "small group of trees", this project called upon different parts of the community to integrate technology with art, in an urban landscape surrounded by nature.

The system is managed completely autonomously by a wind-wheel and a series of 'leaves' from solar-panels, creating different stop areas on the park with open WLAN network as a way to experience the city and the parkland. For that, the acceptance and open mindedness of the users for modern technologies is crucial.

The park presents itself in 5 different modules, like the illustration 1 shows:

- Fukuoka demofield - field moderation

- Green classrooms - school-garden for the students open air classes

- Sport-courses - variable sport-utilization for each age

- Freifunk-Hain - communication-technology and interaction

- Community-equipment - Lokschuppen, the functional restore of the historical old building

From these modules the one chosen for development was 'Freifunk-Hain', by the hands of Mrs. Cordula Loidl-Reisch and Mr. Simon Colwill for Berlin's Technical University.

The goal for Freifunk-Hain was centered on the development of a site that would support WLAN and would be sustainable energy wise. Cross referencing this with the concept of 'Hain', group of small trees, we aimed to create small spaces that would allow users to sit, connect and being transported to a cybernetic reality amongst the vegetation, isolated from the urban chaos.

With the thought of maintaining the biotope that gained it's terrain over the metallurgic reality, emerged the idea of solar panels as if they embodied the 'Hain' though resembling more a group of sunflower crops. Each element is inserted like a small tree that struggles with the untamed vegetation; the non-vertical 'trunk' exposes its texture to every corner of the park (check Illustration 1).

These structures are able to produce enough power for the entire park, Lockschuppen included, maintaining all computer systems. A system of LED lights ${ }^{3}$ (Light Emitting Diode) will also be presented as an indicator of the amount of energy being produced, the temperature and the bytes being transferred at the moment. The whole structure will resemble a work of art, especially at nighttime when the LED lights will glow in the dark.

\footnotetext{
${ }^{3}$ Light Emitting Diode, usually called LED is a small area light source, often with extra optics added to the chip that shapes its radiation pattern. These small lamps can be founded in several colors as blue, green, red and white (Moreno 2006).
} 
This entire park platform still possesses an attached informative structure. A system of cameras will allow to follow the construction evolution of all entire park, as a daily register, analogous what it happened in Potsdamer Platz. It will also allow seeing the conditions of the park at each moment; you can check online the weather conditions or see how busy it is, just before leave home.

These structures will also have TFT-LCD 'touch screens' ${ }^{4}$ with cameras and access to the photo and video blog service lodged in the park website servers (www.freiraumlabor.org). This system will allow the users to take and send pictures or videos to his friends, at the moment or later on from home.

\section{Conclusion}

In conclusion, by the actions of local community a biotope was preserved on the city structure, their actions and their beliefs turn this project possible to happen.

In the near future, users can use this platform "inside" the nature, be connected, read is e-mails, know which temperature is and still take photos or make videos and send to the friends.

We also reach a structure inserted in a biotope preserved on the city, self-sustainable in energy and interactive cybernetic platform that will foment social and communicable relations in Friedrichshain's district.

\section{References}

Bundesamt für Bauwesen und Raumordnung. BBR 2007a. Modellvorhaben Innovationen für familien- und altengerechte Stadtquartiere. Internet website:

http://www.bbr.bund.de/nn_21288/DE/Forschungsprogramme/ExperimentellerWohnun gsStaedtebau/Forschungsfelder/InnovationenFamilieStadtquartiere/Modellvorhaben/10 _MVB_BerlinWriezenerBahnhof.html. Checked in 2007, July $19^{\text {th }}$

Bundesamt für Bauwesen und Raumordnung. BBR 2007. Innovationen für familienund altengerechte Stadtquartiere - Ein xWoSt-Forschungsfeld -32/1 - 03/2007. Bundesamt für Bauwesen und Raumordnung (Hrsg), Bonn 2007

Bezirksamt Friedrichshain-Kreuzberg 1997. B-Plan V42. December 1997

Connor, D., 1995. The development of a biotope classification in Great Britain and Ireland - principles and structure of classification. In: Hiscock, K. (Ed.), Classification of Benthic Marine Biotopes of the North-East Atlantic. Proceedings of a BioMar-Life workshop held in Cambridge, 16-18 November 1994, Cambridge UK, Peterborough, Joint Nature Conservation Committee, pp. 30-46.

I. Moreno (2006). LED Intensity Distribution. International Optical Design, Technical Digest. Internet website:

http://planck.reduaz.mx/ imoreno/Publicaciones/IODC2006.pdf. Checked in 2008 April $15^{\text {th }}$.

\footnotetext{
${ }^{4}$ Thin Film Transistor Liquid Crystal Display, normally called TFT-LCD, is a layer which improves image quality on screens as desk or laptops, providing the user to interact with the system without mouse or keyboard.
} 


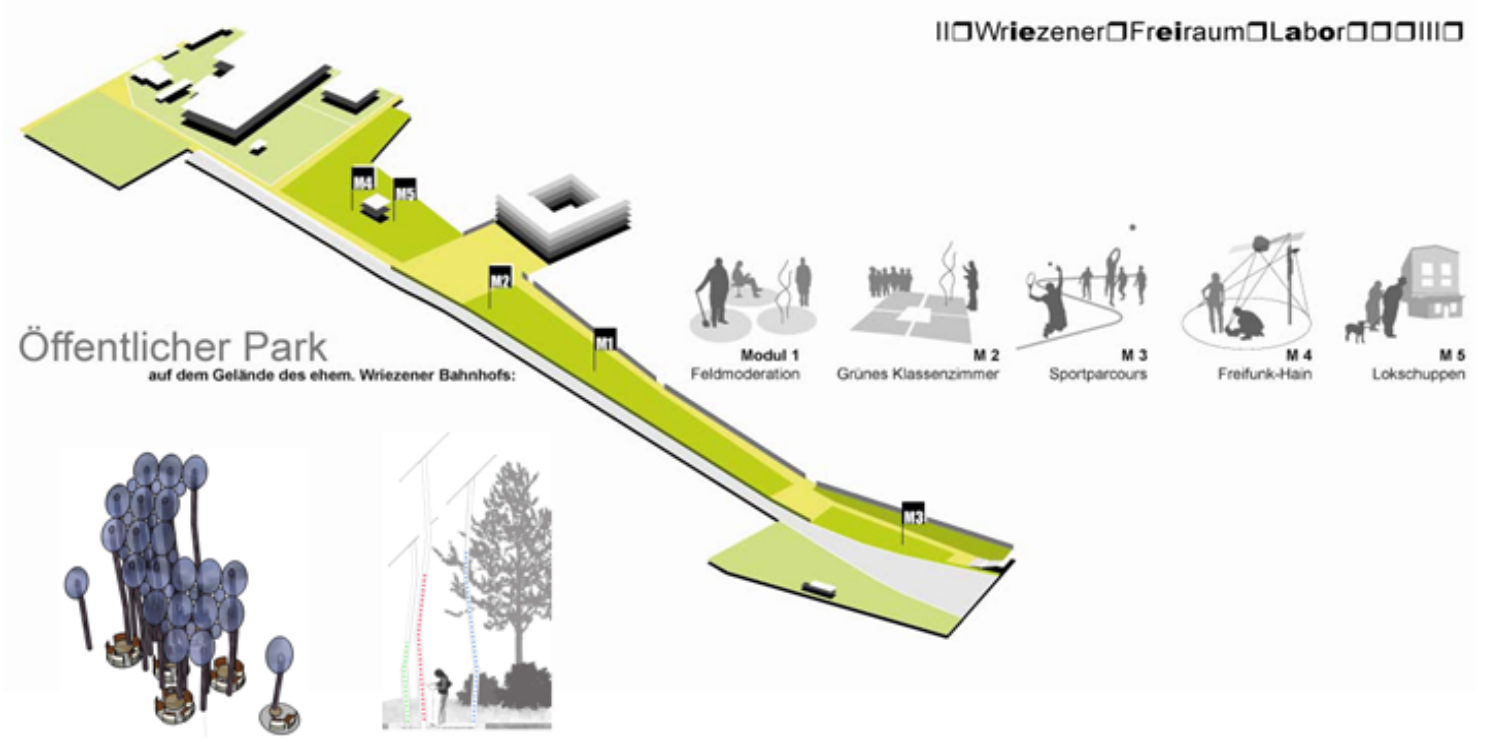

Illustration 1 - "Freifunk-Hain" conceptual view, showing the 5 different modules and a schematic 3D composition resembling the "Hain" sunflowers. 